\title{
Metabolism in blue mussel: intertidal and subtidal beds compared
}

\author{
Morgana Tagliarolo ${ }^{1, *}$, Jacques Clavier ${ }^{1}$, Laurent Chauvaud $^{1}{ }^{,}$Marcel Koken ${ }^{1}$, \\ Jacques Grall ${ }^{2}$
}

${ }^{1}$ Laboratoire des Sciences de l'Environnement Marin, UMR CNRS 6539, and ${ }^{2}$ IUEM Observatory UMS 3113 CNRS, rue Dumont d'Urville, Institut Universitaire Européen de la Mer, 29280 Plouzané, France

\begin{abstract}
Mytilids occur worldwide, and mussel beds are a prominent intertidal and subtidal system feature. Brittany (France) has a complex population structure in which pure genotypes alternate with hybrids of Mytilus edulis and M. galloprovincialis, referred to here as 'mussels'. Mussels live attached to the substrate in subtidal and intertidal areas and are regularly exposed to strong environmental variations (e.g. desiccation, light, and temperature). The resistance of mussels to emersion is based on a combination of different strategies, such as metabolic rate depression, anaerobic metabolism and air breathing. In the present study, we have evaluated the differences in aerial and underwater mussel metabolism between an intertidal mussel bed and a subtidal one. Metabolism was measured seasonally for small (shell length 24 to $26 \mathrm{~mm}$ ) and large $(43$ to $66 \mathrm{~mm}$ ) individuals. Mussel aerial respiration fluxes were directly correlated with air temperature. In contrast, underwater carbon (DIC) fluxes seemed to be influenced by additional factors such as food availability and/or reproduction period. Underwater metabolism was higher in small mussels (intertidal: $35.9 \mu \mathrm{mol}$ DIC g AFDW ${ }^{-1} \mathrm{~h}^{-1}$; subtidal: $51.4 \mu \mathrm{mol} \mathrm{DIC} \mathrm{g} \mathrm{AFDW}{ }^{-1} \mathrm{~h}^{-1}$ ) than in large mussels (intertidal: $26.4 \mu \mathrm{mol}$ DIC g AFDW ${ }^{-1} \mathrm{~h}^{-1}$; subtidal: $21.3 \mu \mathrm{mol} \mathrm{DIC} \mathrm{g} \mathrm{AFDW}{ }^{-1}$ $\mathrm{h}^{-1}$ ). In contrast, aerial respiration showed different adaptations: small intertidal and subtidal mussels had similar respiration under emerged conditions, while large intertidal individuals showed higher carbon fluxes during emersion compared to subtidal individuals. These data suggest that while underwater fluxes were similar for the 2 mussel beds, all small and large intertidal mussels are far better able to tolerate emersion than large subtidal animals. Subtidal mussels seem thus to lose their ability to respire in air after becoming adult.
\end{abstract}

KEY WORDS: Respiration $\cdot$ Mytilus $\cdot \mathrm{CO}_{2} \cdot$ Carbon fluxes $\cdot$ Seasonal variation $\cdot$ Calcification Excretion

Resale or republication not permitted without written consent of the publisher

\section{INTRODUCTION}

The intertidal zone supports a rich and unique biota consisting almost entirely of marine organisms that are dependent on water cover or at least a very wet environment for most of their activities (Little \& Kitching 1996). Intertidal organisms are regularly exposed to large variations in environmental factors, such as temperature, food availability, humidity and salinity. This exposure is particularly true for sessile and sedentary organisms that cannot move to escape from environmental stresses imposed during low tide exposure to air (Nicastro et al. 2010). Intertidal mollusks display a number of specialized adaptations to periodic emersion, correlated with level of exposure. The different adaptive strategies may include resistance mechanisms to elevated temperature and/or desiccation, tissue freeze, and hypoxia and anoxia tolerance (McMahon \& Russel-Hunter 1977, McMahon 1988). 
Mussels are common in coastal water, and they are important species in aquaculture (FAO 2010). The French mussel industry produces $\sim 60000$ metric $\mathrm{yr}^{-1}$, and the 'Bouchots' technique, used in intertidal areas, accounts for the bulk of production in Brittany (Prou \& Goulletquer 2002). In the Mediterranean zone, deep-water longlines and suspended culture techniques are more commonly used. Bivalves, such as mussels and oysters, especially if grown intertidally, tolerate desiccation and are capable of journey times of several days for commercial purposes (Laing \& Spencer 2006).

Environmental differences between the intertidal and subtidal zones provide an excellent opportunity to study the adaptation of species to different habitats. To illustrate adaptive variations independently of phylogeny effects (Stillman \& Somero 2000), we chose to investigate the adaptation to intertidal and subtidal conditions of mussels living in the same area. Acclimatization to intertidal conditions can modify both tolerance to emersion and metabolic rates in Mytilus edulis L. (Demers \& Guderley 1994). Temperature variation is among the most important factors affecting respiration and oxygen consumption in mussels (Bayne 1976, Marsden \& Weatherhead 1998, Jansen et al. 2009). Respiratory adaptation to emersion has mainly been assessed through oxygen flux measurements (Griffiths 1981, Marsden \& Weatherhead 1998, Babarro et al. 2000, Jansen et al. 2009), but intertidal carbon metabolism related to both aerobic and anaerobic respiration and to calcification remains poorly known. Some recent studies on rocky-shore species living in the coastal zone have shown that benthic animals could be a significant source of $\mathrm{CO}_{2}$ for their surrounding environment (Clavier et al. 2009, Lejart et al. 2012). To complement these data, we here investigate the importance of Mytilus spp. in coastal carbon fluxes.

In the present study, we investigated seasonal variations of aquatic and aerial metabolism rates of Mytilus spp. populations, addressing the following questions: Are there respiratory differences between aerial and aquatic $\mathrm{CO}_{2}$ production rates? Are metabolic rates different for intertidal and subtidal mussels? Are intertidal animals better adapted to aerial exposure?

\section{MATERIALS AND METHODS}

\section{Sampling}

Mussels were sampled in a coastal macrotidal ecosystem (maximum tidal amplitude: $8 \mathrm{~m}$; tidal periodicity: 12 h 15 min) from Brittany, France (Fig. 1). Intertidal mussels were collected from the rocky shore at low tide, and subtidal mussels were collected from a mooring in the vicinity of Brest. Intertidal mussels were collected around mean tide level (aerial exposure time rate was $55 \%$ ) and subtidal mussels at a depth of ca. $3 \mathrm{~m}$ below chart datum.

Mussels were collected the day before metabolic measurements were made. They were cleaned of epibionts. In the laboratory, subtidal mussels were kept in running sea water, whereas intertidal mussels were exposed to air during low tide in tanks that simulated the natural tidal cycle. A total of 55 specimens were selected from each site. Mussels were sorted by size and age; their age was determined by counting the rings of winter growth retardation on the shells (Millstein \& O'Clair 2001, Sukhotin et al. 2003). Intertidal and subtidal small (2 to $3 \mathrm{yr}$ old) mussels had a similar average shell length (24 and $26 \mathrm{~mm}$, respectively), while subtidal large (5 to $7 \mathrm{yr}$ old) mussels were larger than intertidal large mus-

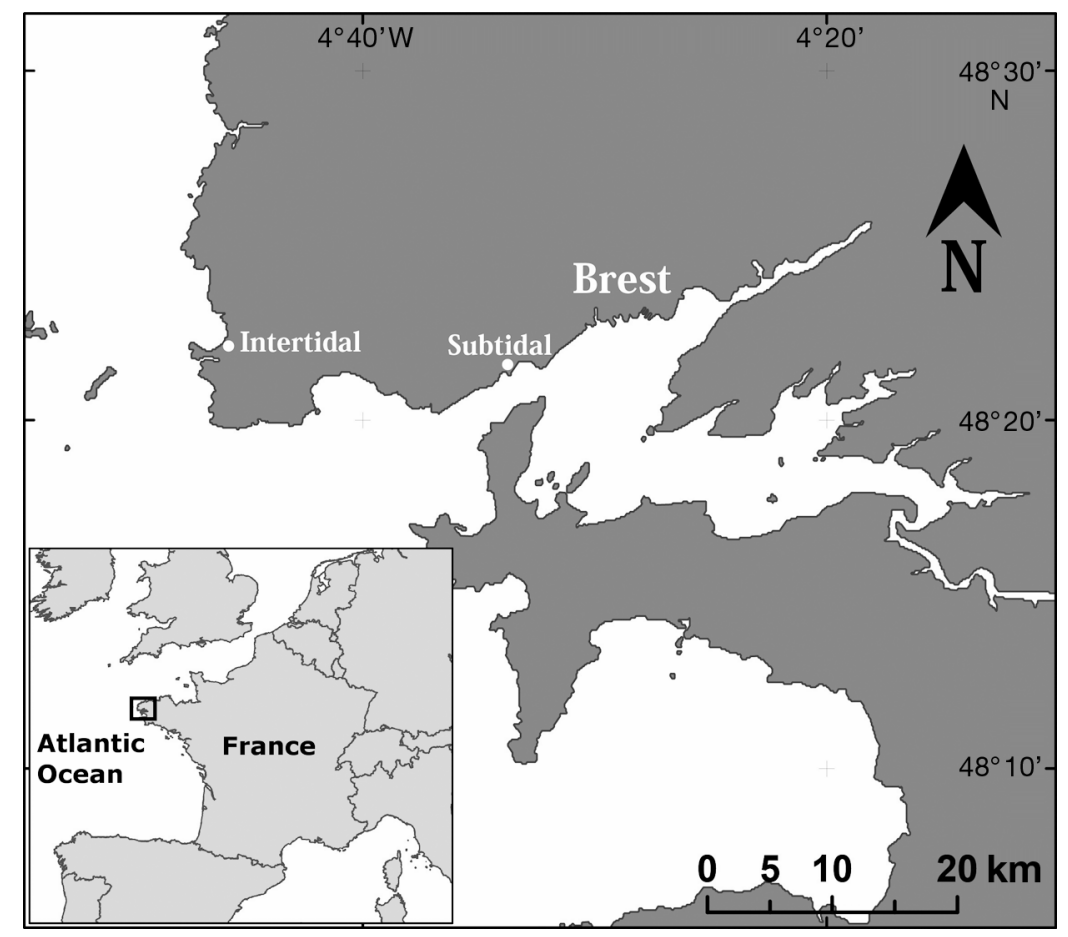

Fig. 1. Sampling sites for intertidal and subtidal mussel respiration measurements in western Brittany (France) 
sels (66 $\mathrm{mm}$ and $43 \mathrm{~mm}$ respectively). The biomass of the specimens was determined by drying at $60^{\circ} \mathrm{C}$ for $24 \mathrm{~h}$ and combusting at $450^{\circ} \mathrm{C}$ for $4 \mathrm{~h}$ in a muffle furnace. The ash mass was then subtracted from the dry mass to obtain the ash-free dry weight (AFDW). All biomass results were expressed as g AFDW.

\section{Genomic DNA analysis}

The blue mussel Mytilus edulis and the Mediterranean mussel M. galloprovincialis Lmk. occur widely on the coasts of northern Europe, and wherever they are sympatric, they hybridize (Gosling et al. 2008). The hybrid zone is large, ranging from the Atlantic coasts of France to northern Scotland, and is spatially complex, containing a mixture of pure, hybrid, and introgressed individuals (Daguin et al. 2001, Gosling et al. 2008). Despite some differences in shell morphology, distinguishing between M. galloprovincialis and $M$. edulis based solely on morphological characters is difficult and highly uncertain due to interbreeding and adaptations to environmental conditions (Gosling 1992).

To identify Mytilus taxa, 10 mussels each from intertidal and subtidal studied zones were sampled for DNA analysis. Mussel foot tissue was powdered in a mortar in liquid nitrogen, and genomic DNA was isolated using a commercial DNA extraction kit (DNeasy blood \& tissue kit, Qiagen) and quantified by UV absorbance spectroscopy. Polymerase chain reaction (PCR) was performed with standard methods (Sambrook et al. 1989) using the following amplification regime: 1 cycle of 5 min at $94^{\circ} \mathrm{C}_{i} 40$ cycles of $30 \mathrm{~s}$ at $94^{\circ} \mathrm{C}, 30 \mathrm{~s}$ at $56^{\circ} \mathrm{C}$, and $1 \mathrm{~min} 30 \mathrm{~s}$ at $72^{\circ} \mathrm{C}_{i} 1 \mathrm{cycle}$ of $10 \mathrm{~min}$ at $72^{\circ} \mathrm{C}_{i}$ 1 cycle of overnight at $4^{\circ} \mathrm{C}$. The primers were designed in the non-repetitive region of the 'foot protein 1 ' gene, coding for one of the adhesive proteins of the Mytilidae that contained inserts or deletions that are species-specific (Inoue et al. 1995).

Amplification with primers Me15 (5'-CCA GTA TAC AAA CCT GTG AAG A-3') and Me16 (5'-TGT TGT CTT AAT AGG TTT GTA AGA-3') gave species-specific fragments of 180 (Mytilus edulis), 168 (M. trunculus), and 126 basepairs (bp) (M. galloprovincialis) respectively (Inoue et al. 1995). Fragments were separated on $5 \%$ NUsieve GTG agarose (FMC Bioproducts) gels.

\section{Aerial respiration}

For metabolic measurements, we used 10 samples, each containing between 1 and 10 individuals and a reference. Aerial $\mathrm{CO}_{2}$ metabolism was measured during short-time incubations in an airtight chamber, using an infrared gas analyzer (Migné et al. 2002). At low tide time, i.e. when the natural population was emerged, animals were placed on a glass table in a climatic room. The indoor air in the climatic room was controlled by an aeration system directly connected with the exterior. Since the laboratory is located near a coastal zone, the air temperature and humidity in the climatic chamber was similar to what is found in the natural environment.

Samples were covered with an opaque chamber with an airtight rubber seal, connected via a closed circuit to the infrared gas analyzer (Li-Cor, LI 820). An adjustable pump maintained an air flow of 0.8 to $0.91 \mathrm{~min}^{-1}$ into the circuit. To dehumidify the air, a desiccation column filled with anhydrous calcium sulfate (Drierite) was placed at the analyzer gas inlet. The $\mathrm{CO}_{2}$ partial pressure $\left(\mathrm{pCO}_{2}\right.$ i in parts per million, $\mathrm{ppm}=\mu \mathrm{mol} \mathrm{CO} \mathrm{Col} \mathrm{air}^{-1}$ ) was displayed on a laptop computer and recorded at $5 \mathrm{~s}$ intervals for $\sim 3 \mathrm{~min}$. Aerial carbon respiration was measured for the 10 samples and a control without mussels every hour for $6 \mathrm{~h}$ to mimic the low tide condition for a natural population. Air temperature and relative humidity $(\mathrm{RH})$ were measured every hour (T200 thermo-hygrometer, Trotec). Since the air of the room was directly pumped from the outside, the air humidity naturally varied with temperature as in the natural environment. Aerial fluxes correspond to the linear slope of the change in $\mathrm{CO}_{2}$ concentration over time during the incubation period, corrected from the net volume of the enclosure and the incubation time.

\section{Ammonium excretion}

Ammonium ions $\left(\mathrm{NH}_{4}{ }^{+}\right)$are the major nitrogenous waste product of aquatic mollusks (Bishop et al. 1983). Excretion of ammonium resulting from the catabolism of organic nitrogen potentially causes an increase in total alkalinity (TA) by 1 equivalent per mole. The rate of ammonia excretion was determined for intertidal and subtidal mussels (large and small individuals) in summer and winter. Samples of water were taken at the beginning and at the end of respiration incubations and stored in $100 \mathrm{ml}$ bottles. Ammonium concentration was determined according to the phenol-hypochlorite method (Solorzano 1969). Reagents were added to the water samples immediately after sampling. After $24 \mathrm{~h}$, sample coloration was measured at $630 \mathrm{~nm}$ (UV-1700 PharmaSpec, UV-VIS spectrophotometer, Shimadzu) using 
Milli-Q water as the blank. Ammonium excretion rates are expressed as $\mu \mathrm{mol} \mathrm{NH}_{4}{ }^{+} \mathrm{g} \mathrm{AFDW}^{-1} \mathrm{~h}^{-1}$.

\section{Calcification}

Net calcification was estimated during immersion only, using the alkalinity anomaly technique (Smith $\&$ Key 1975) based on the fact that TA decreases by 2 equivalents for each mole of $\mathrm{CaCO}_{3}$ precipitated. Net calcification rates $(G)$ in a bottle $\left(\mu\right.$ mol $\left.\mathrm{CaCO}_{3} \mathrm{~h}^{-1}\right)$ were estimated using the following equation:

$$
G=-\frac{\Delta T A \times v}{2 \times \Delta t}
$$

where $\triangle T A$ is the variation of total alkalinity during incubation ( $\left.\mu \mathrm{mol} \mathrm{l}^{-1}\right), v$ is net bottle volume (l), and $\Delta t$ is incubation time $(\mathrm{h})$. Variations in nutrient concentrations may bias estimation of calcification from alkalinity changes. We assumed that in our shorttime incubation, nitrification process variation could be considered insignificant with regard to the total alkalinity variation observed in the present study, and we considered only ammonium production by an excretion process.

\section{Underwater respiration}

During natural high tide, animals were placed in opaque plastic bottles filled with natural filtered seawater directly pumped from the Bay of Brest. Underwater respiration fluxes were assessed during 1 to $1.5 \mathrm{~h}$ incubations. Bottles were kept in the dark and immersed in running sea water pumped from the Bay of Brest to maintain constant temperature matching natural conditions. Water was sampled from each bottle at the beginning and end of incubation. The $\mathrm{pH}$ (total scale) was measured immediately, using a pH meter (Radiometer PH240) standardized with Tris-HCl (2-amino-2-hydroxymethyl-1,3-propanediol) and 2-aminopyridine/HCl buffer solutions in synthetic sea water with a salinity of 35 . TA samples were filtered through $0.7 \mu \mathrm{m}$ Whatman glass fiber filters (GF/F) and stored in $250 \mathrm{ml}$ bottles in the dark. Analyses were carried out within $1 \mathrm{wk}$. TA (mmol $\mathrm{kg}^{-1}$ ) was determined on $20 \mathrm{ml}$ subsamples by Gran automatic potentiometric titration (Radiometer, Titrilab TIM 865) using 0.01 M HCl. Water temperature was measured at the beginning and end of the incubations. Salinity, phosphate, and silicate concentrations were determined using the automated Marel Iroise Station (IUEM-UBO, Observatoire du Domaine
Côtier), located near the pumping station providing the water for these experiments. The concentration of dissolved inorganic carbon (DIC) was calculated from the $\mathrm{pH}, \mathrm{TA}$, temperature, salinity, phosphate, and silicate concentrations (Pierrot et al. 2006). The $\mathrm{CO}_{2}$ dissociation constants $\mathrm{K} 1$ and $\mathrm{K} 2$ (Roy et al. 1993) were used in the computation. Underwater res-

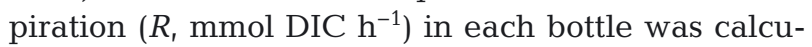
lated according to Eq. (2):

$$
R=-\frac{\Delta D I C \times V}{\Delta t \times 10^{3}}-G
$$

where $G$ is the net $\mathrm{CaCO}_{3}$ flux in a bottle (mmol $\mathrm{CaCO}_{3} \mathrm{~h}^{-1}$ ), $v$ is the bottle volume (l), $\Delta t$ is the incubation time $(\mathrm{h})$, and $\triangle D I C$ is the change in the total inorganic carbon concentration (mmol DIC $1^{-1}$ ).

\section{Calcium carbonate content}

Intertidal and subtidal individuals show different shell thickness and roughness. To help clarify calcification rates, differences among shells were tested with calcium carbonate measures. Calcium carbonate is predominantly found in the shell as outer calcite and the inner aragonite layer associated with the organic matrix (Soído et al. 2009). Five individuals of each intertidal and subtidal studied population were sampled. Soft tissues were removed, and dried shell was ground to obtain fine powder. The mass of shell treated was $0.35 \mathrm{~g}$, dry weight, for all samples. The calcium carbonate of the sample was treated with an excess of hydrochloric acid, and the volume of carbon dioxide gas released was measured using a Bernard apparatus (Hulseman 1966). Results were compared with the volume of $\mathrm{CO}_{2}$ released by pure $\mathrm{CaCO}_{3}$. The carbonate content is expressed as a weight percentage.

\section{Data treatment}

Relationships were established between carbon fluxes during emersion and immersion and mussel AFDW biomass using a functional regression because both fluxes and biomass are affected by natural variability. To analyze the effect of temperature on respiration rates of mussels in emersion and immersion, an Arrhenius plot was established after logarithmic transformation as an inverse function of temperature:

$$
\ln \text { Flux }=\ln a-\frac{E_{\mathrm{a}}}{k} \times \frac{1}{T}
$$




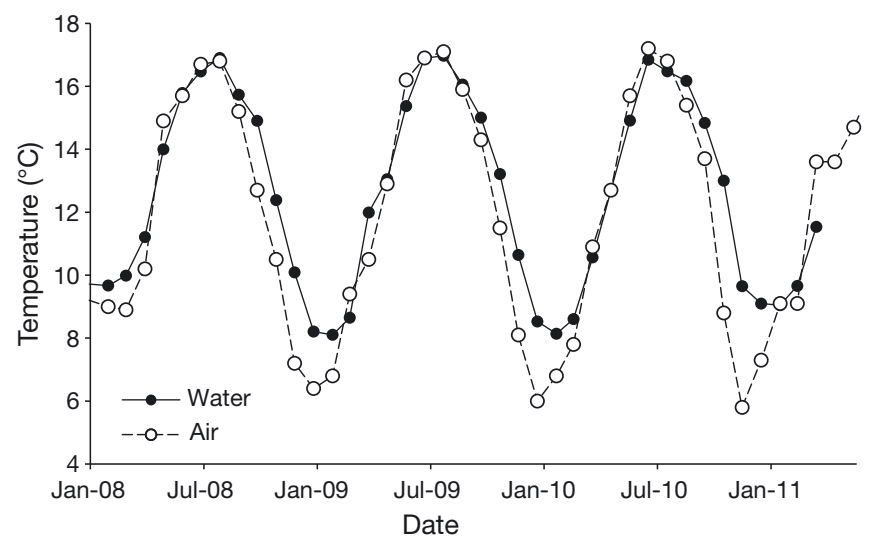

Fig. 2. Monthly variation of mean sea surface (Marel Iroise Station) and air temperature (Météo France, Camaret station) from 2008 to 2011

where Flux is mussel respiration rate $(\triangle \mathrm{DIC}$ underwater or $\Delta \mathrm{CO}_{2}$ in the air, $\left.\mu \mathrm{mol} \mathrm{g} \mathrm{g}^{-1} \mathrm{~h}^{-1}\right), a$ is a normalization constant, $E_{\mathrm{a}}$ is the activation energy $\left(\mathrm{J} \mathrm{mol}^{-1}\right), k$ is Boltzmann's constant $\left(8.31 \mathrm{~J} \mathrm{~K}^{-1} \mathrm{~mol}^{-1}\right)$, and $T$ is the absolute temperature (K). An analysis of variance (ANOVA) test was used to compare Arrhenius linear regression (Sokal \& Rohlf 1995). When samples were too small or not normally distributed, Kruskal-Wallis and Mann-Whitney non-parametric tests were performed.

To estimate $\mathrm{CO}_{2}$ fluxes on an annual scale, average contributions were calculated for aerial and underwater mean annual temperature. The $\mathrm{CO}_{2}$ contribution was calculated considering that subtidal mussels are constantly immersed and that intertidal mussels are exposed to air for $\sim 12 \mathrm{~h} \mathrm{~d}^{-1}$.

\section{RESULTS}

\section{Environmental parameters}

Air and sea surface temperatures were respectively recorded in the bay of Brest at Camaret station (Météo France) and from the Marel Iroise Station, from January 2008 to April 2011 (Fig. 2). Temperature ranged from 5.8 to $17.2^{\circ} \mathrm{C}$ in air and from 8.1 to $17.0^{\circ} \mathrm{C}$ at the sea surface. Average temperature for the studied period was $12.5^{\circ} \mathrm{C}$ for sea water and $12.1^{\circ} \mathrm{C}$ in the air.

\section{Genomic DNA analysis}

Of the 10 intertidal mussels examined, 5 exhibited 2 bands of 126 (Mytilus galloprovincialis specific) and $180 \mathrm{bp}$ ( $M$. edulis specific), whereas the other 5 mussels were homozygous for the $126 \mathrm{bp}$ band (Fig. 3, upper panel). One of the subtidal mussels (Mussel 12) was a heterozygote, and Mussel 15 was homozygous for the $M$. edulis allele. All other animals were homozygous for the M. galloprovincialis type allele (Fig. 3, lower panel).

\section{Aerial respiration}

Carbon dioxide release during emersion differed between large and small mussels (Fig. 4). Aerial respiration of large Mytilus remained stable during the

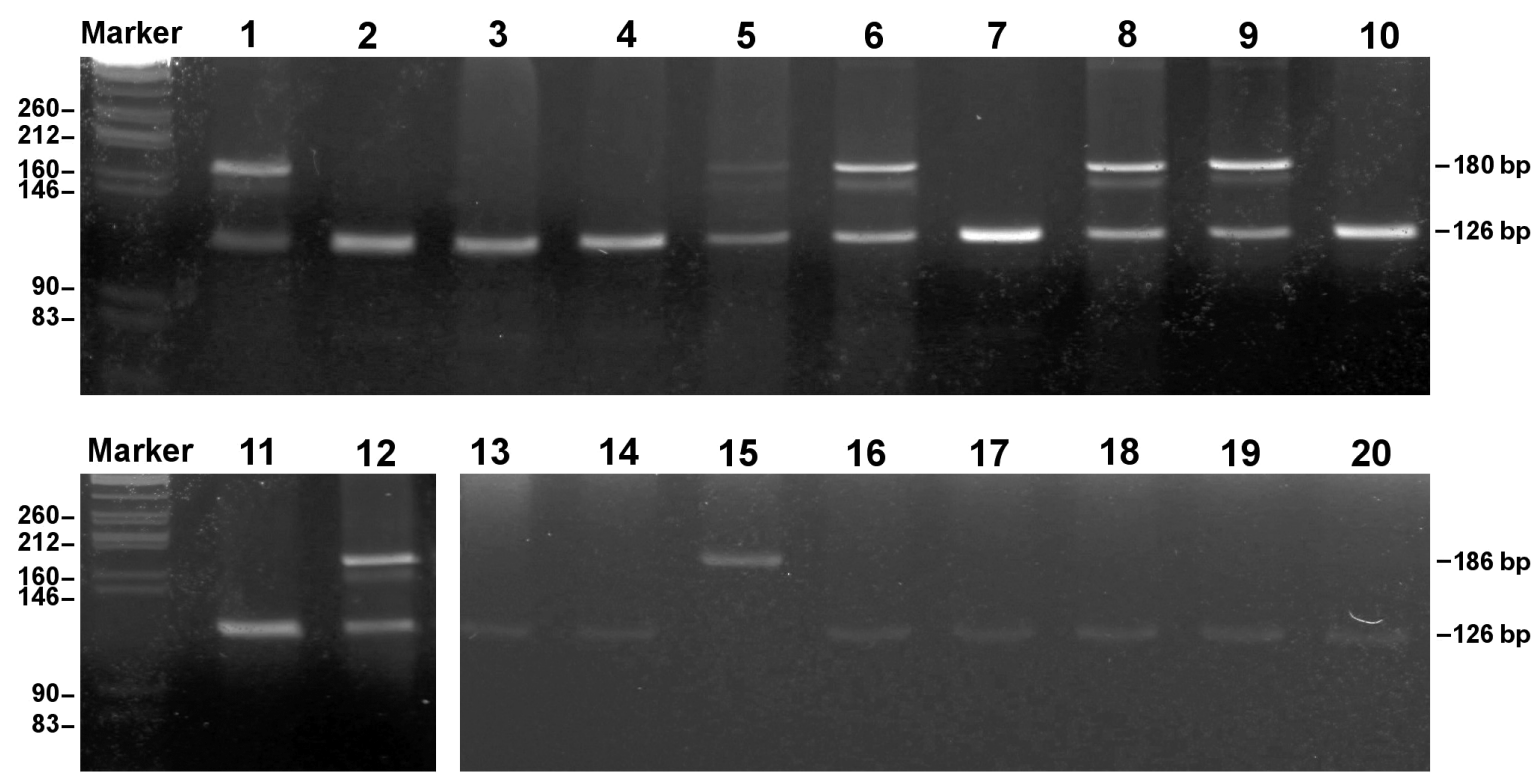

Fig. 3. Agarose gel of the PCR products of the 'Foot protein 1' gene of mussels. The $180 \mathrm{bp}$ product is characteristic of Mytilus edulis, and the 126 bp product is characteristic of M. galloprovincialis. Lanes 1 to 10: intertidal mussels; lanes 11 to 20 : subtidal 

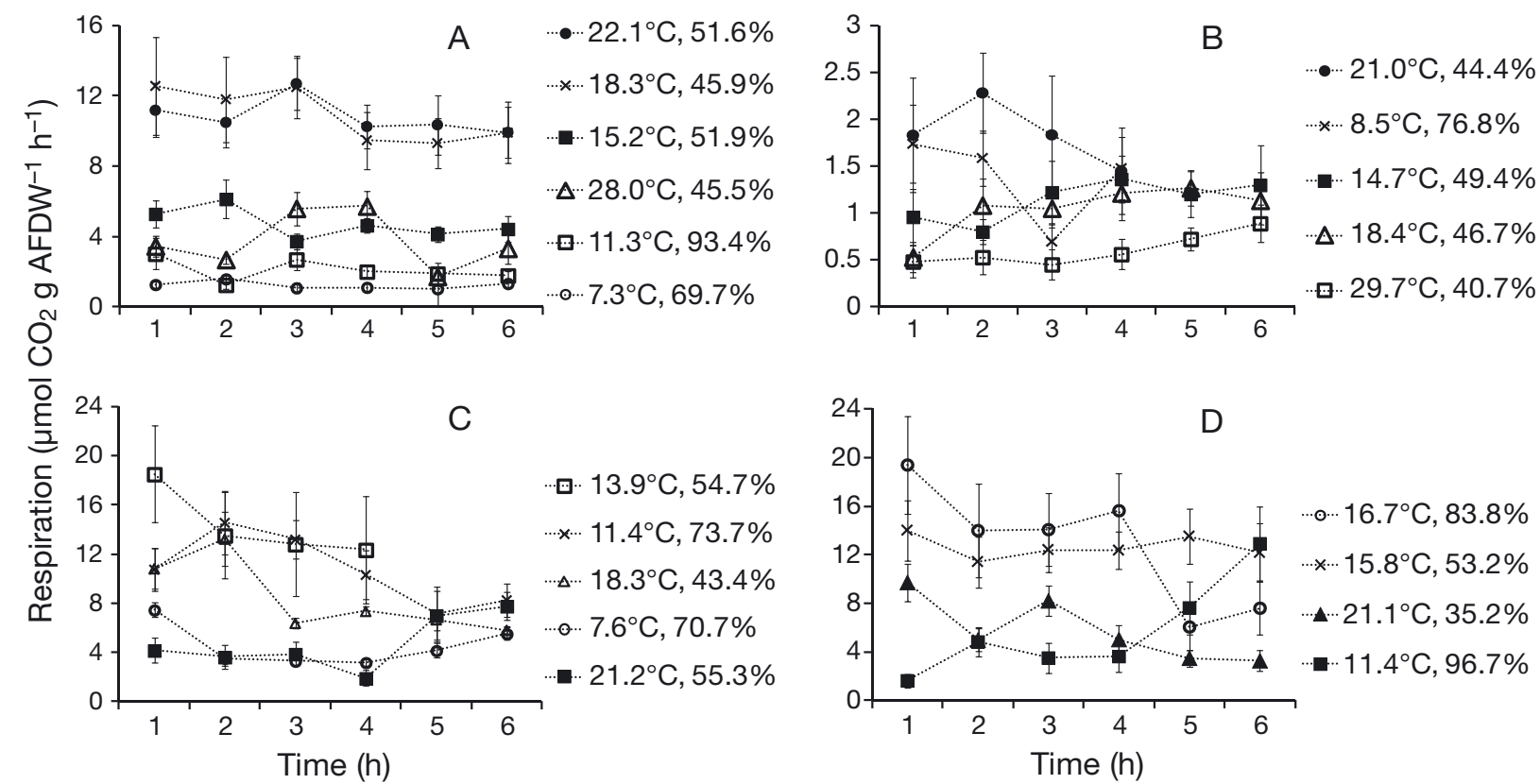

Fig. 4. Mytilus spp. Variation in aerial respiration rates per g AFDW (mean \pm SD) of mussels during the low-tide period at different temperatures $\left({ }^{\circ} \mathrm{C}\right)$ and relative humidity levels $(\%)$, estimated from the variation of $\mathrm{CO}_{2}$ concentration in incubation chambers. (A) large intertidal, (B) large subtidal, (C) small intertidal, (D) small subtidal mussels. AFDW: ash-free dry weight

$6 \mathrm{~h}$ aerial exposure, and slopes did not differ significantly among the temperatures tested (large intertidal ANOVA, $\mathrm{p}=0.55$; large subtidal ANOVA, $\mathrm{p}=$ 0.12) (Fig. 4A,B). Respiration of small mussels was highly variable during the $6 \mathrm{~h}$ emersion. Slopes differed significantly among the temperatures tested (small intertidal ANOVA, $\mathrm{p}=0.00$; small subtidal ANOVA, $p=0.03$ ) (Fig. $4 \mathrm{C}, \mathrm{D}$ ). Large intertidal mussel respiration increased with temperature from 7 to $18^{\circ} \mathrm{C}$ and decreased for higher temperatures. For hot and dry conditions $\left(28^{\circ} \mathrm{C}, 45 \% \mathrm{RH}\right)$, fluxes were always low from the first hour after emersion. Comparatively, large subtidal aerial respiration remained very low during emersion at any tested temperature (Fig. 4B). The lowest respiration was observed at the higher temperature $\left(29^{\circ} \mathrm{C}\right)$ and lower humidity $(40 \%)$. Temperature and atmospheric humidity were significantly related during our experiments $\left(\mathrm{R}^{2}=\right.$ $0.45, \mathrm{p}=0.00)$; thus, our experimental procedure did not allow separate study of the effects of these 2 parameters.

The relationship between temperature and aerial respiration rate was compared for intertidal and subtidal populations (Fig. 5). Intertidal and subtidal large mussels showed different aerial respiration patterns (Fig. 5A), and Arrhenius plots (Table 1) differed significantly for slopes (ANOVA, $\mathrm{p}=0.00$ ). Subtidal large mussels always exhibited low $\mathrm{CO}_{2}$ fluxes (between 0.6 and $1.8 \mu \mathrm{mol} \mathrm{CO} \mathrm{C}_{2} \mathrm{AFDW}^{-1}$

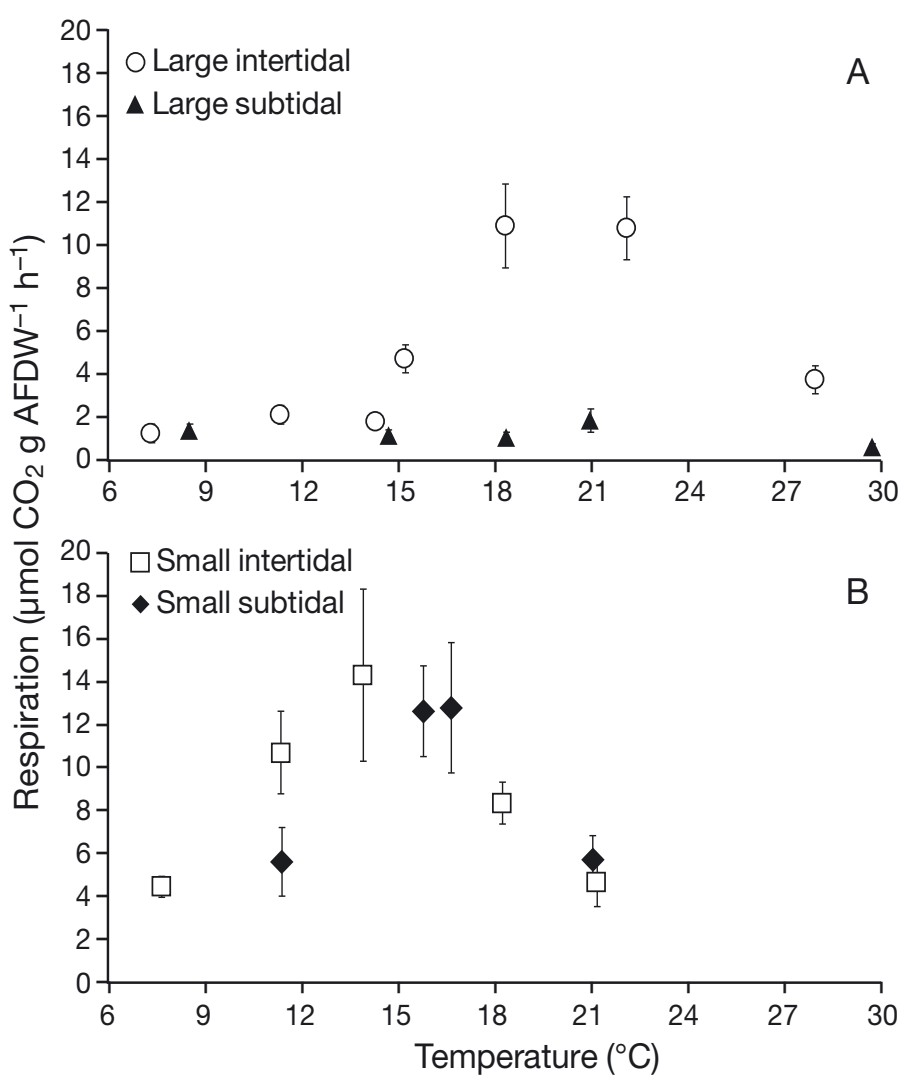

Fig. 5. Mytilus spp. Relationships between intertidal and subtidal hourly aerial respiration rates per g AFDW and temperature (mean $\pm \mathrm{SD}$ ). (A) large mussels, (B) small mussels 
Table 1. Parameters of Arrhenius plots relating the natural logarithm of hourly underwater and aerial respiration per $g$ AFDW to the inverse of absolute temperature (Eq. 3). a: normalization constant; $E_{\mathrm{a}}$ : activation energy $\left(\mathrm{J} \mathrm{mol}^{-1}\right)$; $k$ : Boltzmann's constant $\left(8.31 \mathrm{~J} \mathrm{~K}^{-1} \mathrm{~mol}^{-1}\right)$

\begin{tabular}{|c|c|c|c|c|c|c|c|c|}
\hline & \multicolumn{4}{|c|}{ - Underwater } & \multicolumn{4}{|c|}{ - Air } \\
\hline & \multicolumn{2}{|c|}{ Intertidal } & \multicolumn{2}{|c|}{ Subtidal } & \multicolumn{2}{|c|}{ Intertidal } & \multicolumn{2}{|c|}{ Subtidal } \\
\hline & Small & Large & Small & Large & Small & Large & Small & Large \\
\hline $\operatorname{Ln} a$ & 15.59 & -0.13 & 15.83 & 24.03 & 54.95 & 49.15 & 48.68 & -8.95 \\
\hline$E_{\mathrm{a}} / k$ & 5.49 & 0.97 & 3.47 & 6.02 & 14.99 & 13.77 & 13.35 & 2.64 \\
\hline $\mathrm{R}^{2}$ & 0.25 & 0.03 & 0.15 & 0.37 & 0.97 & 0.83 & 0.98 & 0.35 \\
\hline
\end{tabular}

\section{Calcification}

Net calcification was positive for all mussels tested (Fig. 7). Average uptake was 4.3 and $15.7 \mu \mathrm{mol} \mathrm{CaCO}_{3}$ g $\mathrm{AFDW}^{-1} \mathrm{~h}^{-1}$, for large and small mussels, respectively. Net calcification showed a clear seasonal pattern with minimum values in winter and maximum in summer. Intertidal and subtidal beds did not show significant differences (large $\mathrm{p}=0.47$, small $\mathrm{p}=$ 0.07, Mann-Whitney test). Consider-

$\mathrm{h}^{-1}$ ). Intertidal Mytilus respiration rates increased exponentially with temperature from 7 to $18^{\circ} \mathrm{C}$. Rates measured outside this temperature range did not fit the exponential curve and were found below critical limits for aerobic metabolism. The Arrhenius break temperature (ABT) was between 21 and $24^{\circ} \mathrm{C}$.

Intertidal and subtidal small mussels showed similar fluxes for the same temperature and RH ranges, and Arrhenius plots (Table 1) did not differ significantly for slopes (ANOVA, p = 0.66) (Fig. 5B). For both mussel beds, small animal aerial respiration increased exponentially with temperature; the Arrhenius plot fit $\mathrm{CO}_{2}$ fluxes from 7 to $16^{\circ} \mathrm{C}$ (Table 1). Fluxes decreased for temperatures higher than ABT, with minimal values at $21^{\circ} \mathrm{C}$.

Maximal respiration rates were slightly higher for small (14.3 $\mathrm{mmol} \mathrm{CO}_{2} \mathrm{~g} \mathrm{AFDW}^{-1} \mathrm{~h}^{-1}$ ) than for large intertidal mussels (10.9 $\mu \mathrm{mol} \mathrm{CO}_{2} \mathrm{~g} \mathrm{AFDW}^{-1} \mathrm{~h}^{-1}$ ). Maximal aerial $\mathrm{CO}_{2}$ flux was 7 -fold higher for small than for large subtidal mussels.

\section{Ammonium excretion}

Ammonium fluxes varied from 1.4 to $7.6 \mu \mathrm{mol}$ $\mathrm{NH}_{4} g \mathrm{AFDW}^{-1} \mathrm{~h}^{-1}$ in summer and from 1.2 to $7.0 \mu \mathrm{mol} \mathrm{NH} \mathrm{NH}_{4} \mathrm{~g} \mathrm{AFDW}^{-1} \mathrm{~h}^{-1}$ in winter (Fig. 6). Small mussels showed stronger fluxes than large individuals. Winter and summer ammonium fluxes were significantly different for large and small intertidal mussels (ANOVA, p < 0.01) with higher values during summer. Conversely, large and small subtidal mussels showed similar fluxes during summer and winter. Average $\mathrm{NH}_{4}{ }^{+}$rate was used to correct TA for subtidal mussels. For intertidal mussels, calcification fluxes were corrected with summer and winter ammonium values; spring and autumn analyses were corrected with average $\mathrm{NH}_{4}{ }^{+}$rates. ing that subtidal animals are always immersed and that intertidal mussels are in water for $12 \mathrm{~h} \mathrm{~d}^{-1}$, net calcification fluxes would be slightly lower for large intertidal mussels $\left(0.05 \mathrm{mmol} \mathrm{CaCO}_{3} \mathrm{~g}^{-1} \mathrm{~d}^{-1}\right)$ than for subtidal $\left(0.11 \mathrm{mmol} \mathrm{CaCO}_{3} \mathrm{~g} \mathrm{AFDW}^{-1} \mathrm{~d}^{-1}\right)$.

\section{Underwater respiration}

The relationship between temperature and underwater respiration rate was compared for intertidal and subtidal populations (Fig. 8). Arrhenius plots show that underwater respiration was not directly correlated with temperature (large mussels $\mathrm{R}^{2}=0.10$; small mussels $R^{2}=0.00$ ). Average respiration rates were higher in small (intertidal $35.9 \mu \mathrm{mol}$ DIC g AFDW ${ }^{-1}$ $\mathrm{h}^{-1}$; subtidal $51.4 \mu \mathrm{mol}$ DIC $\mathrm{g} \mathrm{AFDW}^{-1} \mathrm{~h}^{-1}$ ) than in large mussels (intertidal 26.4 $\mu$ mol DIC g AFDW ${ }^{-1} \mathrm{~h}^{-1}$; subtidal 21.3 $\mu$ mol DIC g AFDW ${ }^{-1} \mathrm{~h}^{-1}$ ). Respiration rates differed significantly among the 4 mussel groups (Kruskall-Wallis, $\mathrm{p}<0.05$ ). Comparing mussel groups 2-by-2, significant differences existed between large intertidal and small intertidal and between large subtidal and small intertidal and subtidal mussels (MannWhitney test, $\mathrm{p}<0.05)$.

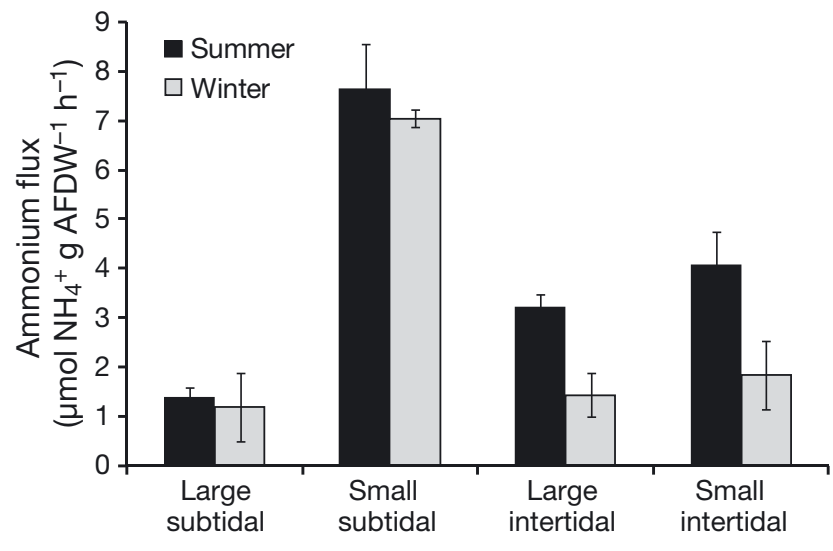

Fig. 6. Mytilus spp. Variation in ammonium excretion rates per $\mathrm{g}$ AFDW (mean $\pm \mathrm{SD}$ ) of mussels during summer and winter 


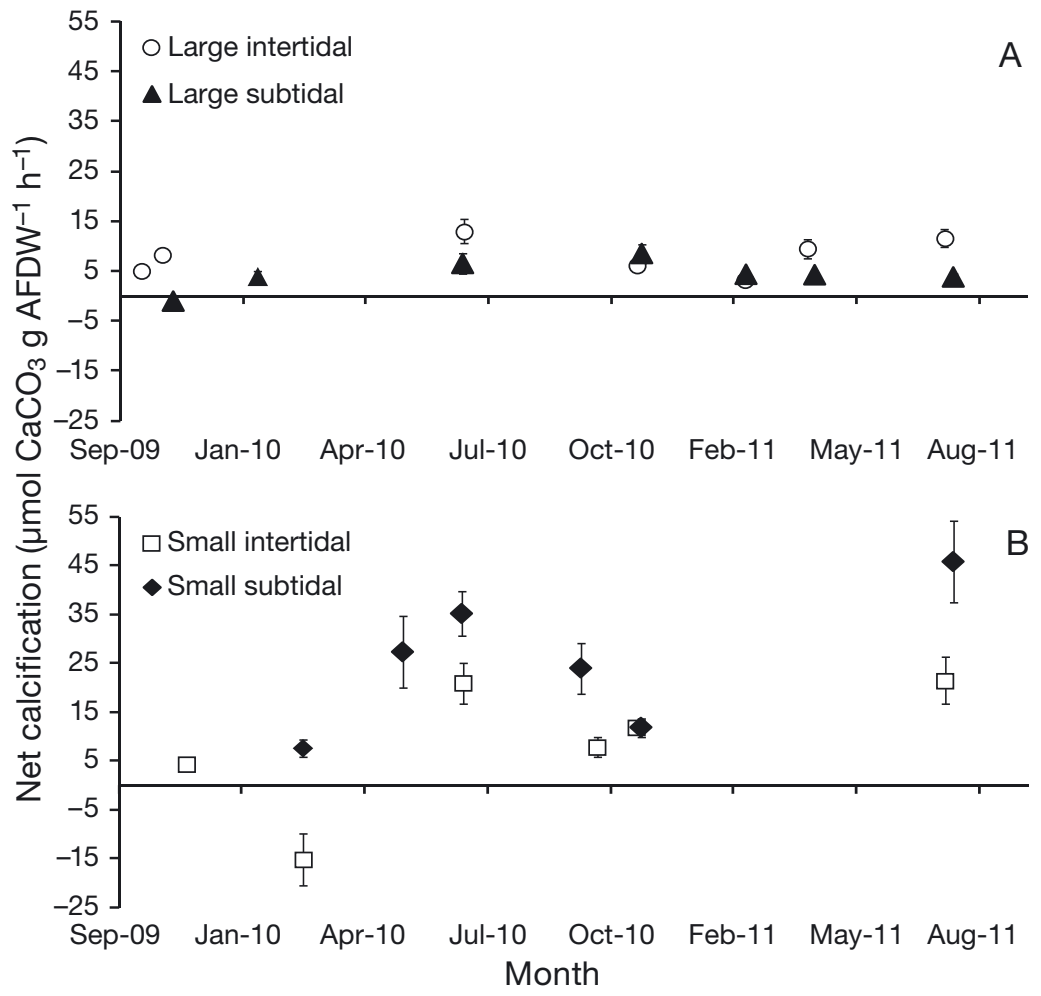

Fig. 7. Mytilus spp. Seasonal variation of net calcification rate (mean \pm SD) estimated from total alkalinity variation during incubation. Positive values correspond to calcification. (A) large mussels, (B) small mussels

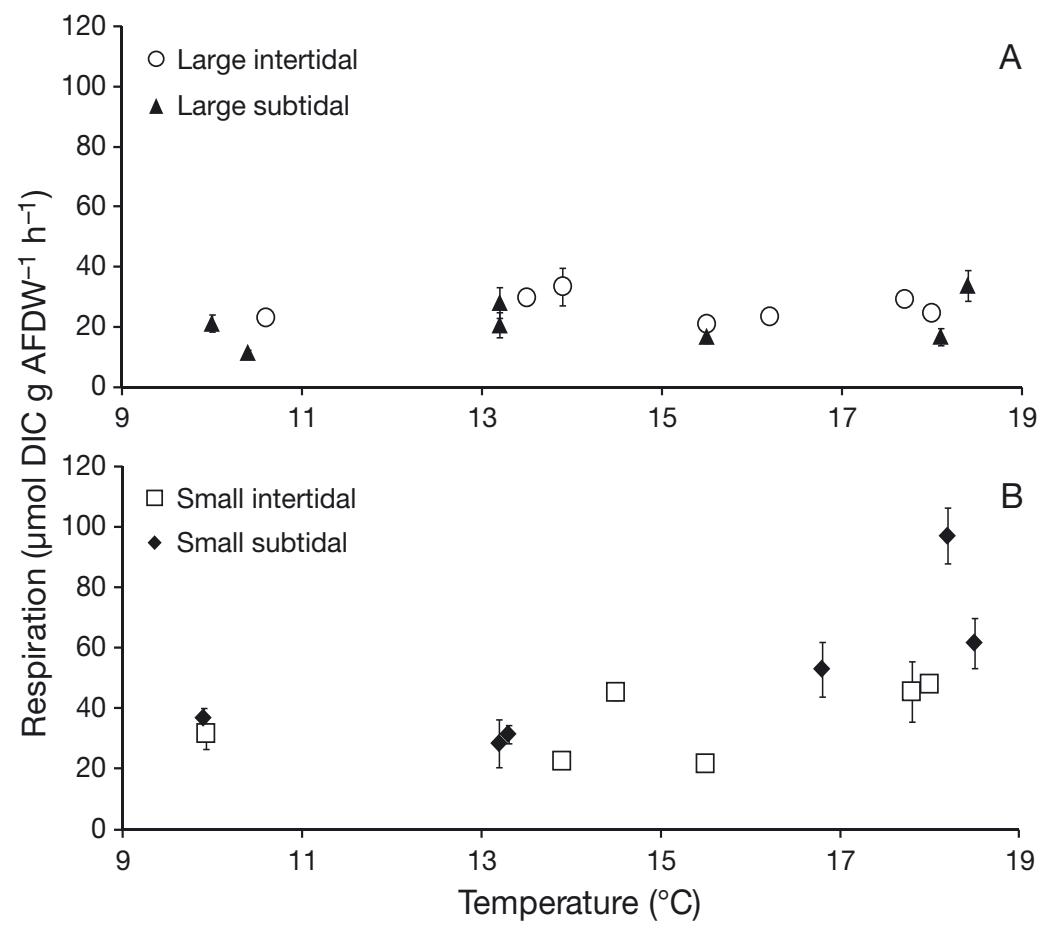

Fig. 8. Mytilus spp. Relationship between intertidal and subtidal hourly underwater respiration (dissolved inorganic carbon, DIC) rates per g biomass (AFDW) and temperature (mean \pm SD). (A) large mussels, (B) small mussels
Considering that subtidal animals are always immersed and intertidal animals are in water for $12 \mathrm{~h} \mathrm{~d}^{-1}$, average underwater respiration fluxes for large Mytilus would be slightly lower for the intertidal (0.32 mmol DIC $g$ AFDW ${ }^{-1} \mathrm{~d}^{-1}$ ) than for the subtidal population $(0.51 \mathrm{mmol}$ DIC g AFDW ${ }^{-1} \mathrm{~d}^{-1}$ ).

Intertidal mussel respiration was higher during submersion than during emersion for all samples (Fig. 9). The aerial:aquatic respiration ratio of 0.2 was the same for large and small intertidal as well as for small subtidal mussels, whereas aerial respiration was less efficient for large subtidal mussels (ratio of 0.06). The Arrhenius plots (Table 1) for underwater and air respiration differed significantly for large intertidal (ANOVA, $p=0.02$ ) but not for the other mussels tested (ANOVA, large subtidal $\mathrm{p}=0.19$; small subtidal $\mathrm{p}=$ 0.24 ; small intertidal $\mathrm{p}=0.20$ ).

\section{Calcium carbonate content}

Mean percentage of calcium carbonate content in subtidal shells was lower $\left(82.46 \pm 2.73 \% \mathrm{CaCO}_{3}\right)$ than in intertidal shells $\left(89.45 \pm 2.52 \% \mathrm{CaCO}_{3}\right)(\mathrm{p}=0.01$, Mann-Whitney test).

\section{$\mathrm{CO}_{2}$ contribution}

The mean total daily $\mathrm{CO}_{2}$ emission by large intertidal and subtidal mussels was estimated at 0.4 and $0.8 \mathrm{mmol} \mathrm{CO}_{2} \mathrm{~g}$ $\mathrm{AFDW}^{-1} \mathrm{~d}^{-1}$, respectively. Mean annual carbon production by large intertidal mussels was $16 \mathrm{~g} \mathrm{C} \mathrm{g} \mathrm{AFDW}^{-1} \mathrm{yr}^{-1}$ and was $29 \mathrm{~g} \mathrm{C} \mathrm{g} \mathrm{AFDW}^{-1} \mathrm{yr}^{-1}$ for large subtidal mussels. For intertidal mussels, the relative contribution of annual carbon sources varied between 28 and $8 \%$ for aerial respiration, 50 and $81 \%$ for underwater respiration, and 22 and $11 \%$ for calcification for small and large animals, respectively. The relative contributions for subtidal mussels were 57 to $85 \%$ for underwater respiration and 43 to $14 \%$ for calcification for small and large animals, respectively. 


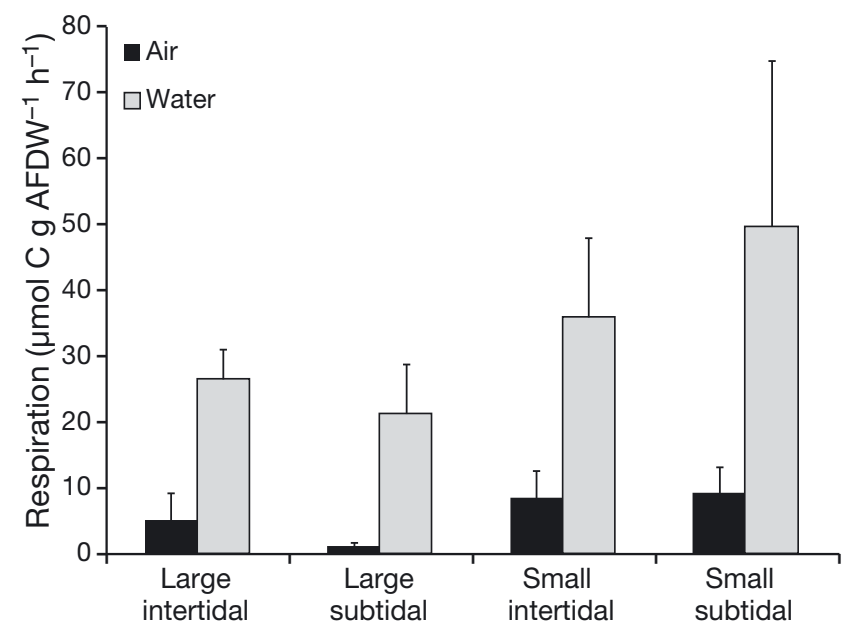

Fig. 9. Mytilus spp. Hourly underwater and aerial carbon respiration (mean $+\mathrm{SD}$ ) of mussels per g AFDW

\section{DISCUSSION}

\section{Genomic DNA analysis}

In the present study, a total of 20 individuals were genotyped for foot-protein-1 alleles through amplification with PCR primers Me15 and Me16. Despite this relatively small sample, our results demonstrate that homozygotes and hybrids are present in both the intertidal and subtidal mussel beds. In the studied area, Mytilus galloprovincialis clearly dominates, as already described by Bierne et al. (2003). In European Atlantic coasts, the spatial distribution of mussel species shows a mosaic structure correlated with environmental factors such as salinity, wave exposure and tidal height at a local scale (Gosling \& Wilkins 1981, Gosling \& McGrath 1990, Bierne et al. 2002, 2003). The different allele compositions between intertidal and subtidal mussels beds have been studied in the Wadden Sea (Luttikhuizen et al. 2002), and no significant differences were detected. Previous studies in mussel metabolism did not test whether individuals belonged to a single species. The genomic analysis permitted testing for the presence of 2 mussel species and their hybrids in the studied zone. Our results suggest that intertidal and subtidal populations had similar species and hybrid compositions.

\section{Aerial respiration}

In the present study, respiration rates were measured in the laboratory where mussels were exposed to ecologically realistic conditions of temperature, humidity and tidal cycle. Body temperature and desiccation rates can significantly affect metabolism and survival of intertidal invertebrates. To clarify the responses of mussels to intertidal conditions, we compared intertidal and subtidal population metabolisms. Intertidal large mussel aerial respiration rates showed clear seasonal variation related to temperature, contrary to subtidal animals that always exhibited low $\mathrm{CO}_{2}$ fluxes during emersion time for all temperatures tested. Large intertidal mussels seemed better adapted to aerial conditions than large subtidal animals. Mussels from higher tidal levels, exposed to periodic emersion, acquire adaptation to air exposure and desiccation with intermittent air breathing 'gaping' behavior and improved water conservation ability (McMahon 1988, 1990, Demers \& Guderley 1994, Sokolova et al. 2000, Sokolova \& Portner 2001). Even if intertidal Mytilus can use atmospheric oxygen through the slight valve gape (gaping) (McMahon 1988), oxygen consumption is 4 to $15 \%$ lower during emersion than during immersion (Widdows et al. 1979, Widdows \& Shick 1985). The ability to retain water in the mantle cavity can provide a most suitable condition for respiratory exchanges and a better ionic regulation. As reported for different mollusks and crustaceans, water stores are progressively depleted and ionic concentration increases during air exposure to avoid variations in hemolymph composition (Wood et al. 1986, Burnett 1988, Truchot 1990). Research on $M$. edulis suggests that differential resistance to prolonged air exposure may also correlate with anaerobic metabolism ability and reduced metabolic energy expenditure capacity (Widdows \& Shick 1985, Demers \& Guderley 1994, Marsden \& Weatherhead 1998). The ability of bivalves to respire anaerobically is well documented (Brinkhoff et al. 1983, Babarro et al. 2007, Connor \& Gracey 2011) and is connected to remarkably high tissue glycogen contents (Hochachka \& Mustafa 1972).

If we assume that the respiration quotient between $\mathrm{O}_{2}$ and $\mathrm{CO}_{2}$ is 1 , the mean aerial respiration rate for large mussels varied between 0.06 and $0.35 \mathrm{mg} \mathrm{O}_{2}$ g $\mathrm{AFDW}^{-1} \mathrm{~h}^{-1}$ for temperatures between 11 and $18^{\circ} \mathrm{C}$. Respiration rates measured in our study are similar to those reported in previous studies, i.e. 0.02 to $0.05 \mathrm{mg} \mathrm{O}_{2} \mathrm{~g}^{-1}$ dry weight (DW) $\mathrm{h}^{-1}$ for temperatures between 10 and $25^{\circ} \mathrm{C}$ (Widdows et al. 1979) and 0.5 to $0.4 \mathrm{mg} \mathrm{O}_{2} \mathrm{~h}^{-1}$ at $14^{\circ} \mathrm{C}$ (Labarta et al. 1997).

The present study showed that small intertidal and subtidal Mytilus aerial $\mathrm{CO}_{2}$ fluxes were similar and mainly controlled by temperature, as indicated by Arrhenius plots. Small mussels showed higher respiratory fluxes than large individuals. In animals with infinite growth, such as mollusks, it is not possible to 
separate the aging effect from the size effect, and any senescence metabolism modification can be masked by the continuously increasing size (Sukhotin \& Flyachinskaya 2009). A decrease in respiration rate with increasing age and weight has already been observed in oyster, limpets, and mussels (Sukhotin \& Pörtner 2001, Martin et al. 2006, Lejart et al. 2012). The driving influence of temperature on respiration is well known in marine mollusks (Newell 1973, Huang \& Newell 2002, Martin et al. 2006). Respiration rates usually increase with temperature until a threshold is reached: the $A B T$, defined as the temperature above which respiration rates drop drastically. Our results showed that aerial fluxes increased with temperature until $24^{\circ} \mathrm{C}$ for large intertidal mussels and until 15 and $18^{\circ} \mathrm{C}$ for small intertidal and subtidal individuals, respectively. The reduction in $\mathrm{CO}_{2}$ fluxes after $\mathrm{ABT}$ temperature may be caused by a limitation in respiratory mechanisms to protect animals from desiccation at higher temperatures. Even if the average monthly air temperature was always $<18^{\circ} \mathrm{C}$, during emersion, different environmental factors can control body temperature. While emerged, an organism's body temperature can be influenced by solar radiation, air temperature, and convective heat exchanges (Helmuth 1998). Consequently, the body temperature in intertidal natural conditions is very likely to increase markedly during low tide (Helmuth \& Hofmann 2001). Smaller animals were more sensitive to high air temperature and may resist summer temperatures (20 to $25^{\circ} \mathrm{C}$ ) by reducing respiration rates and living closer to the thermal limits. In many species, stress resistance increases with the developmental stage of the animal, and different metabolic factors or shell structural properties may explain thermal tolerance variability (Wallis 1975, Sukhotin et al. 2003).

\section{Underwater respiration}

Most respiration rates given for mollusks are based on $\mathrm{O}_{2}$ underwater measurements (Widdows 1973, Bayne et al. 1976, Simpfendörfer et al. 1995), whereas the associated carbon release is still poorly characterized. If we consider that the respiration quotient between $\mathrm{O}_{2}$ and $\mathrm{CO}_{2}$ is 1 , mean respiration rates for the large mussels that we measured corresponded to $1.23 \mathrm{mg} \mathrm{O}_{2} \mathrm{~g} \mathrm{AFDW}^{-1} \mathrm{~h}^{-1}$ for the average annual temperature of $13^{\circ} \mathrm{C}$. Respiration rates measured in our study are slightly higher than those given in previous studies: $0.32 \mathrm{mg} \mathrm{O}_{2} \mathrm{~g}^{-1} \mathrm{DW} \mathrm{h} \mathrm{h}^{-1}$ at $15^{\circ} \mathrm{C}$ for Mytilus edulis (Widdows 1973), $0.6 \mathrm{mg} \mathrm{O}_{2} \mathrm{~g} \mathrm{DW}^{-1} \mathrm{~h}^{-1}$ at $10^{\circ} \mathrm{C}$ for $M$. edulis (Widdows et al. 1979), and 0.4 to $0.8 \mathrm{mg} \mathrm{O}_{2} \mathrm{~g}^{-1}$ shell-free $\mathrm{DW} \mathrm{h} \mathrm{h}^{-1}$ at $13^{\circ} \mathrm{C}$ for $M$. galloprovincialis (Jansen et al. 2009).

In most laboratory studies, aquatic respiration is measured at active (maximal activity) or routine rates (normal activity). In our experiment, fluxes were measured in filtered seawater where mussels cannot feed, and the respiratory rate reflected the standard or inactive rate. Our results showed that aerial respiration was strongly size dependent. As observed for aerial fluxes, underwater respiration was higher for small animals. Mussels seem unable to maintain high aerial respiration rates when body size increases.

Within the studied temperature range $\left(9\right.$ to $\left.19^{\circ} \mathrm{C}\right)$, DIC fluxes were relatively temperature independent, as reported for Mytilus edulis and $M$. californianus (Widdows 1973, Bayne 1976). A change in the level of activity appears to be a major factor in the process of metabolic compensation in response to temperature (Widdows 1973). In the present study, underwater respiration rates seemed more influenced by reproduction period and food availability. Extreme carbon fluxes (not shown in Fig. 8) of 50 to $60 \mu \mathrm{mol} \mathrm{g} \mathrm{AFDW}^{-1}$ $\mathrm{h}^{-1}$ were recorded during gamete release and strong food availability periods (sea surface chlorophyll fluorescence data; Marel Iroise data). The variation of food expressed as chlorophyll a concentrations is an important factor influencing seasonal respiration patterns in M. galloprovincialis (Babarro et al. 2000).

\section{Aerial/underwater comparison}

Respiration responses of mussels were strongly different between the immersion and emersion period. While underwater carbon fluxes did not vary with temperature, aerial fluxes were highly influenced by temperature variations. During emersion, some intertidal bivalves breathe at a rate similar to that in water (Bayne et al. 1976, Widdows \& Shick 1985); however, this is not a general feature for mussels. We found that aerial respiration represented $23 \%$ of underwater respiration for small intertidal, 19\% for large intertidal and small subtidal, and only $5.6 \%$ for large subtidal mussels. A similar study in Mytilus edulis showed that aerial rates ranged from 14 to $20 \%$ of underwater rates (Widdows \& Shick 1985).

\section{Ammonium excretion}

Ammonia fluxes are highly variable because of influences from several factors, such as temperature, season and reproductive cycle. (Gabbott \& Bayne 
1973) In the present study, mussel size strongly influenced respiration and excretion; small mussels showed stronger excretion fluxes per biomass unit. In marine bivalves, excretion rate increases with individual biomass; however, the rate of excretion per unit biomass decreases as an individual grows larger (Vaughn \& Hakenkamp 2001). Summer and winter rates of ammonium excretion for large mussels (1.2 and $3.2 \mu \mathrm{mol} \mathrm{g} \mathrm{AFDW}^{-1} \mathrm{~h}^{-1}$, respectively) were comparable to results of previous studies in Mytilus edulis $\left(\sim 1.13 \mu \mathrm{mol} \mathrm{g}{ }^{-1} \mathrm{~h}^{-1}\right)$ (Thomsen \& Melzner 2010). Ammonia rates follow seasonal changes; in $M$. edulis, excretion is known to be maximal in spring and summer and minimal in winter (Bayne \& Scullard 1977).

\section{Calcification and calcium carbonate content}

The alkalinity anomaly technique is a sensitive and appropriate technique for short-term studies of calcification fluxes in individual organisms (Chisholm \& Gattuso 1991, Gazeau et al. 2007). Excretion of ammonium resulting from the catabolism potentially causes an increase in total alkalinity by 1 equivalent per mole. In the present study, $\mathrm{CaCO}_{3}$ fluxes were corrected with ammonium rates calculated during the summer and winter period, and the correction increased $\mathrm{CaCO}_{3}$ fluxes on average by $13 \%$. These results confirm that ammonium effects on AT are smaller than the variability observed in calcification estimates (Jacques \& Pilson 1980, Chisholm \& Gattuso 1991, Gazeau et al. 2007).

As reported in several studies (Malone \& Dodd 1967, Lutz \& Clark 1984, Martin et al. 2006, Clavier et al. 2009, Lejart et al. 2012), annual variation in invertebrate carbonate deposition is marked. This technique has been only used in a previous study that aimed to assess mussel calcification rates. The comparison with our data remains difficult because rates were expressed on a fresh weight basis (net calcification rates between -0.2 and $0.6 \mu \mathrm{mol} \mathrm{CaCO}_{3} \mathrm{~g} \mathrm{FW}^{-1}$ $\mathrm{h}^{-1}$ ) (Gazeau et al. 2007). In our study, net $\mathrm{CaCO}_{3}$ fluxes were clearly season dependent, with higher calcification in spring and summer and a predominance of carbonate dissolution in winter. Environmental factors, e.g. temperature and salinity, influence the mineralogy and calcification of mussel shell (Taylor et al. 1973). During the warm summer months, regular crystals are deposited, but as water temperature declines, crystal growth ceases and the shell may even be eroded as calcium carbonate apparently buffers the acidic end-products of anaer- obic metabolism (Lutz \& Clark 1984). The effect of these and other factors, such as aerial exposure, on crystal growth determines the rate of shell deposition.

Our results show that small individuals precipitated more $\mathrm{CaCO}_{3}$ per biomass unit than large individuals and that they were more influenced by seasonal variability. With increasing size, the growth rate declines due to reduced relative metabolic activity and reduced rate of water transport and food uptake in larger mussels (Bayne 1976, Kautsky 1982). Small mussels may also suffer from intraspecific feeding competition, obtaining more advantage with increasing size (Kautsky 1982).

The growth rate of Mytilus spp. depends on the tidal period and increases with time of submergence because during the uncovering period, calcification is not possible (Pannella 1976, Buschbaum \& Saier 2001). Mussels can develop morphological variations in response to environmental conditions during their life. In our study, large subtidal mussels were much larger than intertidal animals at the same age, while their shells were thinner with lower calcium carbonate content. Large intertidal mussels' mean hourly $\mathrm{CaCO}_{3}$ fluxes were almost double compared to large subtidal mussel fluxes. Even if hourly calcification rates are higher for intertidal animals, daily fluxes are slightly higher for subtidal mussels, considering that intertidal individuals are immersed only $12 \mathrm{~h} \mathrm{~d}^{-1}$.

Animals from the high intertidal zone exhibited lower growth rates than those permanently immersed. Previous studies have confirmed that Mytilus edulis and Perna canaliculus (Gmelin, 1791) from higher tidal levels possess relatively thicker shells and larger adductor muscles (Lewis \& Seed 1969, Hickman \& Illingworth 1980). Mollusks with solid shells are more likely to withstand exposure to waves, drying, and temperature variations (Vermeij 1972, Alyakrinskaya 2005). We show here that intertidal mussels have a smaller but stronger shell than subtidal animals, an important feature used to protect animals during aerial exposure.

\section{$\mathrm{CO}_{2}$ contribution}

Annual carbon fluxes of intertidal large Mytilus spp. are mainly due to underwater respiration. The calcification contribution was significant, with a ratio of $11 \%$ of total fluxes for intertidal and $14 \%$ for subtidal mussels. Our results show that $\mathrm{CO}_{2}$ released by calcification processes is similar to previous values given for bivalves, $25 \%$ for Crassostrea gigas (Lejart et al. 
2012), and $33 \%$ for Potamocorbula amurensis (Chauvaud et al. 2003). Further studies on intertidal hard substrate species will allow calculations of the contribution of the whole intertidal community to $\mathrm{CO}_{2}$ emissions.

Mussel beds are dense heterotrophic communities that are economically and ecologically important to the coastal zone. The present study demonstrates that Mytilus spp. metabolism significantly contributes to $\mathrm{CO}_{2}$ release in both the intertidal and subtidal zones.

Acknowledgements. The present study was supported by the ANR CHIVAS (Chimie des Valves de la Coquille Saint Jacques Européenne) program. We thank Marel Iroise for sea surface temperature (www-iuem.univ-brest.fr/ observatoire/marel.php). Data were collected and processed according to the terms of the framework agreement jointly signed by IFREMER, CNRS (Institut National des Sciences de l'Univers) and Université de Bretagne Occidentale (on behalf of Institut Universitaire Européen de la Mer) (no. 11/2-210922). We thank the SOMLIT group for providing nutrient data and gas-analyser calibration (http://somlit. epoc.u-bordeaux1.fr/fr/). We thank E. Amice and R. Marc for diving support and M. Mercier for calcium carbonate analysis.

\section{LITERATURE CITED}

Alyakrinskaya I (2005) Functional significance and weight properties of the shell in some mollusks. Biol Bull (Woods Hole) 32:397-418

> Babarro JMF, Fernández-Reiriz MJ, Labarta U (2000) Metabolism of the mussel Mytilus galloprovincialis from two origins in the Ría de Arousa (north-west Spain). J Mar Biol Assoc UK 80:865-872

> Babarro JMF, Labarta U, Reiriz MJF (2007) Energy metabolism and performance of Mytilus galloprovincialis under anaerobiosis. J Mar Biol Assoc UK 87:941-946

Bayne BL (1976) Marine mussels, their ecology and physiology, Vol 10. Cambridge University Press, Cambridge

> Bayne BL, Scullard C (1977) Rates of nitrogen excretion by species of Mytilus (Bivalvia: Mollusca). J Mar Biol Assoc UK 57:355-369

Bayne BL, Bayne C, Carefoot T, Thompson R (1976) The physiological ecology of Mytilus californianus Conrad. Oecologia 22:229-250

Bierne N, David P, Boudry P, Bonhomme F (2002) Assortative fertilization and selection at larval stage in the mussels Mytilus edulis and M. galloprovincialis. Evolution 56:292-298

- Bierne N, Borsa P, Daguin C, Jollivet D, Viard F, Bonhomme F, David P (2003) Introgression patterns in the mosaic hybrid zone between Mytilus edulis and M. galloprovincialis. Mol Ecol 12:447-461

Bishop SH, Ellis LL, Burcham JM (1983) Amino acid metabolism in molluscs. In: Hochachka PW (ed) The Mollusca: metabolic biochemistry and molecular biomechanics, Vol 1. Academic Press, New York, NY, p 234-327

Brinkhoff W, Stöckmann K, Grieshaber M (1983) Natural occurrence of anaerobiosis in molluscs from intertidal habitats. Oecologia 57:151-155

Burnett LE (1988) Physiological responses to air exposure: acid-base balance and the role of branchial water stores. Am Zool 28:125-135

> Buschbaum C, Saier B (2001) Growth of the mussel Mytilus edulis L. in the Wadden Sea affected by tidal emergence and barnacle epibionts. J Sea Res 45:27-36

> Chauvaud L, Thompson JK, Cloern JE, Thouzeau G (2003) Clams as $\mathrm{CO}_{2}$ generators: the Potamocorbula amurensis example in San Francisco Bay. Limnol Oceanogr 48: 2086-2092

> Chisholm JRM, Gattuso JP (1991) Validation of the alkalinity anomaly technique for investigating calcification and photosynthesis in coral reef communities. Limnol Oceanogr 36:1232-1239

Clavier J, Castets MD, Bastian T, Hily C, Boucher G, Chauvaud L (2009) An amphibious mode of life in the intertidal zone: aerial and underwater contribution of Chthamalus montagui to $\mathrm{CO}_{2}$ fluxes. Mar Ecol Prog Ser 375:185-194

Connor K, Gracey AY (2011) High resolution analysis of metabolic cycles in the intertidal mussel Mytilus californianus. Am J Physiol Regul Integr Comp Physiol 302: R103-R111

> Daguin C, Bonhomme F, Borsa P (2001) The zone of sympatry and hybridization of Mytilus edulis and M. galloprovincialis, as described by intron length polymorphism at locus mac-1. Heredity 86:342-354

> Demers A, Guderley H (1994) Acclimatization to intertidal conditions modifies the physiological response to prolonged air exposure in Mytilus edulis. Mar Biol 118: $115-122$

FAO (2010) The state of world fisheries and aquaculture2010. FAO Fisheries and Aquaculture Department, Rome

Gabbott P, Bayne B (1973) Biochemical effects of temperature and nutritive stress on Mytilus edulis L. J Mar Biol Assoc UK 53:269-286

> Gazeau F, Quiblier C, Jansen J, Gattuso JP, Middelburg JJ, Heip CHR (2007) Impact of elevated $\mathrm{CO}_{2}$ on shellfish calcification. Geophys Res Lett 34:L07603, doi:10.1029/ 2006GL028554

Gosling EM (1992) The mussel Mytilus: ecology, physiology, genetics, and culture, Vol 25. Elsevier, Amsterdam

Gosling EM, McGrath D (1990) Genetic variability in exposed-shore mussels, Mytilus spp., along an environmental gradient. Mar Biol 104:413-418

Gosling EM, Wilkins NP (1981) Ecological genetics of the mussels Mytilus edulis and M. galloprovincialis on Irish coasts. Mar Ecol Prog Ser 4:221-227

> Gosling E, Doherty S, Howley N (2008) Genetic characterization of hybrid mussel (Mytilus) populations on Irish coasts. J Mar Biol Assoc UK 88:341-346

> Griffiths RJ (1981) Aerial exposure and energy balance in littoral and sublittoral Choromytilus meridionalis (Kr.) (Bivalvia). J Exp Mar Biol Ecol 52:231-241

Helmuth BST (1998) Intertidal mussel microclimates: predicting the body temperature of a sessile invertebrate. Ecol Monogr 68:51-74

Helmuth BST, Hofmann GE (2001) Microhabitats, thermal heterogeneity, and patterns of physiological stress in the rocky intertidal zone. Biol Bull (Woods Hole) 201:374-384

Hickman R, Illingworth J (1980) Condition cycle of the green-lipped mussel Perna canaliculus in New Zealand. Mar Biol 60:27-38

Hochachka PW, Mustafa T (1972) Invertebrate facultative 
anaerobiosis: a reinterpretation of invertebrate enzyme pathways suggests new approaches to helminth chemotherapy. Science 178:1056-1060

- Huang SC, Newell R (2002) Seasonal variations in the rates of aquatic and aerial respiration and ammonium excretion of the ribbed mussel, Geukensia demissa (Dillwyn). J Exp Mar Biol Ecol 270:241-255

Hulseman J (1966) On the routine analysis of carbonates in unconsolidated sediments. J Sediment Petrol 36:622-625

> Inoue K, Waite JH, Matsuoka M, Odo S, Harayama S (1995) Interspecific variations in adhesive protein sequences of Mytilus edulis, M. galloprovincialis, and M. trossulus. Biol Bull (Woods Hole) 189:370-375

> Jacques T, Pilson M (1980) Experimental ecology of the temperate scleractinian coral Astrangia danae I. Partition of respiration, photosynthesis and calcification between host and symbionts. Mar Biol 60:167-178

> Jansen JM, Hummel H, Bonga SW (2009) The respiratory capacity of marine mussels (Mytilus galloprovincialis) in relation to the high temperature threshold. Comp Biochem Physiol A Mol Integr Physiol 153:399-402

Kautsky N (1982) Growth and size structure in a baltic Mytilus edulis population. Mar Biol 68:117-133

Labarta U, Fernández-Reiriz MJ, Babarro JMF (1997) Differences in physiological energetics between intertidal and raft cultivated mussels Mytilus galloprovincialis. Mar Ecol Prog Ser 152:167-173

Laing I, Spencer B (2006) Bivalve cultivation: criteria for selecting a site, Vol 136. CEFAS Sci Ser Tech Rep 136, CEFAS, Weymouth

Lejart M, Clavier J, Chauvaud L, Hily C (2012) Respiration and calcification of Crassostrea gigas: contribution of an intertidal invasive species to coastal ecosystem $\mathrm{CO}_{2}$ fluxes. Estuaries Coasts 35:622-632

Lewis JR, Seed R (1969) Morphological variation in Mytilus from south-west England in relation to the occurrence of Mytilus galloprovincialis. Cah Biol Mar 10:231-253

Little C, Kitching J (1996) The biology of rocky shores. Oxford University Press, Oxford

> Luttikhuizen PC, Koolhaas A, Bol A, Piersma T (2002) Mytilus galloprovincialis-type foot-protein-1 alleles occur at low frequency among mussels in the Dutch Wadden Sea. J Sea Res 48:241-245

Lutz RA, Clark GR (1984) Seasonal and geographic variation in the shell microstructure of a salt-marsh bivalve (Geukensia demissa (Dillwyn)). J Mar Res 42:943-956

Malone PG, Dodd JR (1967) Temperature and salinity effects on calcification rate in Mytilus edulis and its paleoecological implicatons. Limnol Oceanogr 12:432-436

Marsden ID, Weatherhead MA (1998) Effects of aerial exposure on oxygen consumption by the New Zealand mussel Perna canaliculus (Gmelin, 1791) from an intertidal habitat. J Exp Mar Biol Ecol 230:15-29

Martin S, Thouzeau G, Chauvaud L, Jean F, Guérin L, Clavier J (2006) Respiration, calcification, and excretion of the invasive slipper limpet, Crepidula fornicata L.: implications for carbon, carbonate, and nitrogen fluxes in affected areas. Limnol Oceanogr 51:1996-2007

McMahon RF (1988) Respiratory response to periodic emergence in intertidal molluscs. Integr Comp Biol 28:97-114

> McMahon RF (1990) Thermal tolerance, evaporative water loss, air-water oxygen consumption and zonation of intertidal prosobranchs: a new synthesis. Hydrobiologia 193:241-260

McMahon RF, Russel-Hunter WD (1977) Temperature rela- tion of aerial and aquatic respiration in six littoral snails in relation to their vertical zonation. Biol Bull (Woods Hole) 152:182-198

Migné A, Davoult D, Spilmont N, Menu D, Boucher G, Gattuso JP, Rybarczyk H (2002) A closed-chamber $\mathrm{CO}_{2}$ flux method for estimating intertidal primary production and respiration under emersed conditions. Mar Biol 140: 865-869

Millstein J, O'Clair C (2001) Comparison of age-length and growth-increment general growth models of the Schnute type in the Pacific blue mussel, Mytilus trossulus Gould. J Exp Mar Biol Ecol 262:155-176

Newell R (1973) Factors affecting the respiration of intertidal invertebrates. Integr Comp Biol 13:513-528

> Nicastro K, Zardi G, McQuaid C, Stephens L, Radloff S, Blatch G (2010) The role of gaping behaviour in habitat partitioning between coexisting intertidal mussels. BMC Ecol 10:17

Pannella G (1976) Tidal growth patterns in recent and fossil mollusc bivalve shells: a tool for the reconstruction of paleotides. Naturwissenschaften 63:539-543

Pierrot D, Lewis E, Wallace D (2006) MS Excel program developed for $\mathrm{CO}_{2}$ system calculations. In: ORNL/ CDIAC-105, US Department of Energy. Carbon Dioxide Information Analysis Center, Oak Ridge National Laboratory, Oak Ridge, TN, http://cdiac.ornl.gov/ftp/co2sys/ CO2SYS_calc_XLS/

Prou J, Goulletquer P (2002) The French mussel industry: present status and perspectives. Bull Aquacult Assoc Can 102:17-23

Roy RN, Roy LN, Vogel KM, Porter-Moore C and others (1993) The dissociation constants of carbonic acid in seawater at salinities 5 to 45 and temperatures 0 to $45^{\circ} \mathrm{C}$. Mar Chem 44:249-267

Sambrook J, Fritsch E, Maniatis T (1989) Molecular cloning: a laboratory manual, Vol 3. Cold Spring Harbor Laboratory Press, New York, NY

Simpfendörfer RW, Vial MV, López DA, Verdala M, González ML (1995) Relationship between the aerobic and anaerobic metabolic capacities and the vertical distribution of three intertidal sessile invertebrates: Jehlius cirratus (Darwin) (Cirripedia), Perumytilus purpuratus (Lamarck) (Bivalvia) and Mytilus chilensis (Hupé) (Bivalvia). Comp Biochem Physiol B Biochem Mol Biol 111: $615-623$

> Smith S, Key G (1975) Carbon dioxide and metabolism in marine environments. Limnol Oceanogr 20:493-495

> Soído C, Vasconcellos MC, Diniz AG, Pinheiro J (2009) An improvement of calcium determination technique in the shell of molluscs. Braz Arch Biol Technol 52:93-98

Sokal RR, Rohlf FJ (1995) Biometry: the principles and practice of statistics in biological research. WH Freeman, New York, NY

Sokolova IM, Pörtner HO (2001) Physiological adaptations to high intertidal life involve improved water conservation abilities and metabolic rate depression in Littorina saxatilis. Mar Ecol Prog Ser 224:171-186

Sokolova IM, Granovitch AI, Berger VJ, Johannesson K (2000) Intraspecific physiological variability of the gastropod Littorina saxatilis related to the vertical shore gradient in the White and North Seas. Mar Biol 137:297-308

Solorzano L (1969) Determination of ammonia in natural waters by the phenolhypochlorite method. Limnol Oceanogr 14:799-801

Stillman JH, Somero GN (2000) A comparative analysis 
of the upper thermal tolerance limits of eastern Pacific porcelain crabs, genus Petrolisthes: influences of latitude, vertical zonation, acclimation, and phylogeny. Physiol Biochem Zool 73:200-208

Sukhotin AA, Flyachinskaya LP (2009) Aging reduces reproductive success in mussels Mytilus edulis. Mech Ageing Dev 130:754-761

Sukhotin AA, Pörtner HO (2001) Age-dependence of metabolism in mussels Mytilus edulis (L.) from the White Sea. J Exp Mar Biol Ecol 257:53-72

Sukhotin AA, Lajus DL, Lesin PA (2003) Influence of age and size on pumping activity and stress resistance in the marine bivalve Mytilus edulis L. J Exp Mar Biol Ecol 284; 129-144

Taylor JD, Kennedy WJ, Hall A (1973) The shell structure and mineralogy of the Bivalvia. British Museum (Natural History), London

Thomsen J, Melzner F (2010) Moderate seawater acidification does not elicit long-term metabolic depression in the blue mussel Mytilus edulis. Mar Biol 157:2667-2676

Truchot JP (1990) Respiratory and ionic regulation in invertebrates exposed to both water and air. Annu Rev Physiol

Editorial responsibility: Peter Beninger,

Nantes, France
52:61-76

> Vaughn CC, Hakenkamp CC (2001) The functional role of burrowing bivalves in freshwater ecosystems. Freshw Biol 46:1431-1446

Vermeij GJ (1972) Intraspecific shore-level size gradients in intertidal molluscs. Ecology 53:693-700

- Wallis RL (1975) Thermal tolerance of Mytilus edulis of Eastern Australia. Mar Biol 30:183-191

Widdows J (1973) The effects of temperature on the metabolism and activity of Mytilus edulis. Neth J Sea Res 7: 387-398

Widdows J, Shick J (1985) Physiological responses of Mytilus edulis and Cardium edule to aerial exposure. Mar Biol 85:217-232

Widdows J, Bayne BL, Livingstone DR, Newell RIE, Donkin $P$ (1979) Physiological and biochemical responses of bivalve molluscs to exposure to air. Comp Biochem Physiol 62:301-308

Wood CM, Boutilier R, Randall D (1986) The physiology of dehydration stress in the land crab, Cardisoma carnifex: respiration, ionoregulation, acid-base balance and nitrogenous waste excretion. J Exp Biol 126:271-296

Submitted: March 7, 2012; Accepted: July 25, 2012

Proofs received from author(s): November 5, 2012 